\title{
GEOLOGIC MAP OF THE RED BLUFF 30' $\times$ 60' QUADRANGLE, CALIFORNIA
}

\author{
By M.C. Blake, Jr., D.S. Harwood, E.J. Helley, W.P. Irwin, A.S. Jayko, and D.L. Jones
}

\section{DESCRIPTION OF MAP UNITS}

\author{
SACRAMENTO VALLEY- \\ CASCADE RANGE PROVINCE
}

\section{Sedimentary rocks}

$t$

Qsc

Qa

Qo

Qao

Qb ground disturbed by man timeters in bedrock canyons channels modern streams
Dredge tailings (Holocene)-Also includes other

Stream channel deposits (Holocene)-Gravel, sand, and silt deposited in open, active stream channels without permanent vegetation. Deposits are being transported under modern hydrologic conditions, and, consequently, are light colored (tan and gray), unweathered, and usually in contact with modern surface waters. Thickness varies from $25 \mathrm{~m}$ on Sacramento River to less than a few cen-

Alluvium (Holocene) - Gravel, sand, and silt deposited by present-day streams and rivers; derived from Tehama and Tuscan Formations and from rocks in Coast Ranges and Klamath Mountains. Differentiated from older and younger units chiefly on the basis of geomorphic position in modern stream

Overbank deposits (Holocene)—Sand, silt, and minor lenses of gravel deposited by floods and high-water stages on low terraces adjacent to present-day alluvial channels

Alluvial and overbank deposits, undivided (Holocene)-Gravel, sand, and silt deposited by normal and high-water flows in

Basin deposits (Holocene)-Fine-grained silt and clay

Modesto Formation (Pleistocene)-Deposits in two terraces that show very fresh dispositional morphology and little, if any, erosional features. Terraces probably were deposited by same stream systems that flow today because they generally border existing channels. Derived from heterogeneous metamorphic, sedimentary, and volcanic rocks. Divided into:
Qmu

Qml

Qru

Qrl

Qrb
Upper member-Gravel, sand, silt, and clay found on lower Modesto terrace. Lithologically similar to lower member except that soils lack pedogenic B horizon. Unit is less than 3 meters thick

Lower member-Gravel, sand, silt, and clay found on upper Modesto terrace. Soils contain pedogenic B horizon. Unit is less than 5 meters thick

Riverbank Formation (Pleistocene)—Deposits in two terraces cut and filled into surface of Red Bluff Formation. Divided into:

Upper member-Gravel, sand, silt, and clay found on lower Riverbank terrace. Lithologically similar to Modesto Formation but differentiated from it on the basis of both higher geomorphic position and greater degree of soil formation. Soils display medial development with strong textures, B horizons, and local hardpans. Lithologically very similar to, but more widespread than, lower member. Terrace surfaces are geomorphically lower and generally smoother than those of lower member, and, in addition, soil profile is not as well developed as that on lower member. Unit is less than 10 meters thick

Lower member-Gravel, sand, silt, and clay found on higher Riverbank terrace. Derived from heterogeneous metamorphic, sedimentary, and volcanic rocks; lithologically similar to Red Bluff Formation but is slightly finer grained and contains less gravel. Lower member is more eroded than upper member

Red Bluff Formation (Pleistocene) - Very coarse, red (2.5-5YR) gravel that contains minor amounts of interstratified sand and silt. Red Bluff deposits located west of Sacramento River were derived from metamorphic rocks of Coast Ranges and Klamath Mountains. Volcanic-clast fanglomerate in eastern part of quadrangle was derived from Tuscan Formation and lava flows and is correlated with Red Bluff Formation to west. All Quaternary alluvial deposits except older gravel deposits (unit QTog) are deposited 
in channels eroded into Red Bluff Formation. Red Bluff Formation is overlain by 0.4 Ma Rockland ash bed of Sarna-Wojcicki and others (1982), and it overlies olivine basalt of Deer Creek (1.08 Ma; Harwood and others, 1981) $25 \mathrm{~km}$ southeast of city of Red Bluff. Maximum thickness is $5 \mathrm{~m}$

QTog Older gravel deposits (Pleistocene and (or) Pliocene)—Reddish- to yellowish-tan, moderately well indurated coarse gravel and minor amounts of coarse sand that rest unconformably on eroded soil profile developed on Tuscan Formation near The Hogback and in Salt Creek east of city of Red Bluff. Clasts are well-rounded, locally deeply weathered volcanic fragments apparently derived from Tuscan Formation. At Deer Creek, $5 \mathrm{~km}$ south of quadrangle, older gravel deposits unconformably underlie olivine basalt of Deer Creek (1.08 Ma; Harwood and others, 1981). Red Bluff Formation unconformably overlies older gravel deposits in Salt Creek. Maximum thickness is $65 \mathrm{~m}$

Tehama Formation (Pliocene)—Fluvial deposits of pale-green, gray, and tan sandstone, tuffaceous sandstone, and siltstone and lenses of crossbedded pebble and cobble conglomerate derived both from metamorphic rocks of Coast Ranges and Klamath Mountains and from volcanic rocks of Tuscan Formation. Interfingers with Tuscan Formation in vicinity of Sacramento River. Maximum thickness is about $600 \mathrm{~m}$ near city of Red Bluff. Locally includes:

Tten Nomlaki Tuff Member-Dacitic pumice tuff found at or near base of both Tehama and Tuscan Formations; see description under Tuscan Formation in subsection entitled "Volcanic rocks"

Tc Channel deposits (Pliocene and (or) Miocene) Tan or yellowish-tan to reddish-brown cobble conglomerate and sandstone exposed below Nomlaki Tuff Member of Tuscan Formation at Tuscan Springs and in some deeper canyons along Chico Monocline southeast of quadrangle. Well-rounded clasts include greenstone, gray quartzite, red, green, and black chert, white vein quartz, and lesser amounts of green and gray phyllite. Varied amounts of subrounded basalt and basalticandesite clasts are intermixed with metamorphic rock fragments. Maximum thickness is about $20 \mathrm{~m}$

Kc Chico Formation (Late Cretaceous)-Tan, yellowish-brown to light-gray, fossiliferous marine sandstone; lenticular beds of pebble to cobble conglomerate; and minor siltstone. Exposed at Tuscan Springs, in Salt Creek, and in Sevenmile Creek south of Tuscan Buttes. Conglomerate clasts are rounded to well rounded and consist of red, green, and black chert, white vein quartz, quartzite, granite, and greenstone. Calcite cement and fossil fragments are common at Tuscan Springs. Sandstone is composed of fine- to medium-grained, angular to subrounded grains of quartz, plagioclase, alkali feldspar, lithic fragments, and detrital chert. Thickness is unknown

Volcanic rocks

Basaltic rocks of Inskip Hill volcanic center (Holocene)-Divided into:

Qip Basalt flow of Paynes Creek-Thin, black to dark-gray, olivine-bearing, high-alumina, diktytaxitic basalt flow. Erupted from Inskip Hill, $5 \mathrm{~km}$ east of Soap Butte; flowed westward in Inks Creek and Paynes Creek, reaching Sacramento River at Chinese Rapids. Northeast of Dales near quadrangle boundary, thickness of Paynes Creek basalt flow is about $8 \mathrm{~m}$; at Manton Road $2 \mathrm{~km}$ northeast of Dales Lake, about $2 \mathrm{~m}$; at Chinese Rapids, about $10 \mathrm{~m}$. Age of Paynes Creek basalt flow is unknown but must be about 10,000 yr B.P. or less because flow overlies alluvium assigned to upper member of Modesto Formation in tributary of Inks Creek

Qiu Basalt flows of Inskip Hill and Soap Butte, undivided-Several high-alumina olivine basalt flows that originate at Soap Butte and Inskip Hill, $5 \mathrm{~km}$ east of Soap Butte. Thickness of flows is unknown but their limited distribution suggests that they are thin, nearvent deposits

Basaltic rocks of Black Butte volcanic center (Holocene)_Divided into:

Qbc Cinder deposits-Black, well-bedded, fine- to coarse-grained basaltic cinders, which form dissected ejecta blanket that ranges in thickness from about $10 \mathrm{~m}$ in cinder pit on Ash Creek to about $1.5 \mathrm{~m}$ on south rim of Lack Creek near northeast corner of quadrangle

Qbb Basalt flow of Black Butte-Black to lightgray, high-alumina olivine basalt flow, which issued from vent that ultimately built Black Butte cinder cone $0.5 \mathrm{~km}$ east of quadrangle. One branch of flow moved 
about $1 \mathrm{~km}$ west of vent into upper reaches of Rancheria Creek; other branch cascaded over Battle Creek Fault scarp just east of quadrangle boundary. Basalt consists of olivine and clinopyroxene phenocrysts scattered in diktytaxitic matrix of clinopyroxene and plagioclase; accessory minerals include abundant magnetite in matrix and minor amounts of euhedral spinel within olivine phenocrysts. Maximum thickness is $6 \mathrm{~m}$

Qtbb

Basalt near Tuscan Buttes (Holocene and (or) Pleistocene)—Gray, reddish-gray to black, glomeroporphyritic to highly vesicular, high-alumina basalt and minor amounts of scoria. Exposed on west flank of Tuscan Buttes and in Sevenmile Creek to southwest. Morphology of deposits suggests small, local extrusions of basalt along approximately north trending fissure system after much, if not all, of present local relief on surface of Tuscan Formation had formed by uplift and erosion

Qab Hypersthene andesite of Brokeoff Mountain (Pleistocene)-Porphyritic hypersthene andesite channeled along Battle Creek Fault Zone in northeast part of quadrangle. Unit is continuous with andesite of Brokeoff Mountain mapped by Macdonald and Lydon (1972) in Whitmore 15' quadrangle. Rock is dark gray to black and contains abundant white plagioclase phenocrysts as long as $5 \mathrm{~mm}$. Scattered glomeroporphyritic aggregates of plagioclase, honey-yellow phenocrysts of hypersthene, and rare augite are set in fine-grained matrix of plagioclase microlites and brown glass. Flow is about $6 \mathrm{~m}$ thick

Qr Rockland ash bed of Sarna-Wojcicki and others (1982) (Pleistocene)-Loosely aggregated, dacitic pumice lapilli ash (Wilson, 1961) that contains scattered, coarse, white pumice fragments as much as $20 \mathrm{~cm}$ in diameter. Pumiceous fragments are composed primarily of silky white, wispy, vesicular glass that contains scattered crystals of glassy to white plagioclase and sanidine, green hornblende, hypersthene, and minor magnetite. Found as scattered erosional remnants of large, nonwelded ashflow sheet that erupted $34 \mathrm{~km}$ east of quadrangle. North of Digger Buttes, about $15 \mathrm{~km}$ east of quadrangle, ash-flow tuff is at least $60 \mathrm{~m}$ thick but is generally less than $5 \mathrm{~m}$ thick in scattered patches to west.
Fission-track age of 0.4 Ma (C.E. Meyer and A.M. Sarna-Wojicki, unpub. data, 1984, in Sarna-Wojicki and others, 1985; see also, Meyer and others, 1991)

Basalt flows of Shingletown Ridge (Pleistocene)-At least three flows of highalumina olivine basalt exposed in northeastern part of quadrangle. Flows were mapped in Whitmore 15' quadrangle by Macdonald and Lydon (1972) and traced eastward to Red Mountain Lake area in Manzanita Lake 15' quadrangle by Macdonald (1963), where they apparently originated from several vents along fissure system that trends north-northwest from vicinity of Lassen Peak. Dark-gray, fine-grained, diktytaxitic and locally porphyritic basalt contains rounded phenocrysts of brownish-green olivine scattered in openwork-mesh matrix of plagioclase and clinopyroxene. Maximum thickness of individual flows is about $5 \mathrm{~m}$. Divided into: Flow 3

Flow 2

Flow 1

Olivine basalt of Eagle Canyon (Pleistocene) Dark-gray, diktytaxitic, vesicular olivine basalt exposed on walls of Eagle Canyon (1 km east of quadrangle) in Battle Creek along foot of Battle Creek Fault scarp above coarse bouldery volcanic fanglomerate. Wilson (1961, p. 11) grouped rocks comprising olivine basalt of Eagle Canyon, fanglomerate mapped as Red Bluff Formation in this report, and underlying basalt of Coleman Forebay into his Long Ranch basalt unit. Maximum thickness is about $4 \mathrm{~m}$; source unknown

Qbd Olivine basalt of Devils Half Acre (Pleistocene)-Gray, glomeroporphyritic, vesicular olivine basalt that shows well-developed columnar jointing on north rim of Antelope Creek. Aggregates of strongly zoned plagioclase as much as $10 \mathrm{~mm}$ in diameter and euhedral to subhedral olivine as much as $5 \mathrm{~mm}$ in diameter are set in ophitic matrix of nearly equal amounts of plagioclase microlites and clinopyroxene. Magnetite is scattered in matrix; knee-shaped twinned high-relief crystals of rutile(?) included in plagioclase microlites. Maximum thickness is $15 \mathrm{~m}$; source unknown Basalt of Coleman Forebay (Pleistocene)Olivine basalt flows that underlie volcanic fanglomerate, correlated with the Red 
Bluff Formation, in several isolated areas that extend from Coleman Forebay on Battle Creek Fault scarp southward to vicinity of Hog Lake. Rock is light-rustygray-weathering, dark-gray olivine basalt that has pronounced diktytaxitic texture, as well as scattered large vesicles and voids that form large rounded pits on weathered surfaces. Maximum thickness is $10 \mathrm{~m}$; source unknown

Andesite (Pleistocene and (or) Pliocene)—Gray, greenish-gray, red, and grayish-tan, finegrained, sparsely porphyritic, locally flowbanded andesite preserved as erosional remnant of larger flow that caps Tuscan Buttes. Phenocrysts of basaltic hornblende variably altered to dustlike particles of magnetite are set in matrix of oriented, flowtrained microlites of plagioclase. Interstices are filled with either very fine grained plagioclase(?) or silica mineral after glass. Maximum thickness is $35 \mathrm{~m}$; source unknown

Tuscan Formation (Pliocene)_Divided into:

Undivided part-Interbedded lahar deposits, volcanic conglomerate, volcanic sandstone, and pumiceous tuff

Member D-Block-and-ash deposits composed of juvenile andesitic pyroclastic debris and interbedded lahar deposits; characterized by large monolithologic masses of gray hornblende andesite, augiteolivine basaltic andesite, and black pumiceous mudstone, as well as smaller fragments of black obsidian and white and gray, hornblende-bearing pumice, all in grayish-tan pumiceous-mudstone matrix. Distinguished from member $\mathrm{C}$ by presence of large, fractured monolithologic rock masses, black obsidian fragments, and white and dove-gray pumice fragments. Thickness ranges from about 10 to 50 meters Tuff member of Hogback Road-Discontinuous unit of well-bedded lapilli tuff, pumiceous conglomerate, and sandstone. Contains abundant, well-rounded, white, hornblendebearing dacitic pumice clasts as much as 3 $\mathrm{cm}$ in diameter and lesser amounts of smaller, well-rounded, light-gray and black andesitic pumice clasts. Tuff rests unconformably on deformed and locally eroded older units of Tuscan Formation but appears to be conformable beneath member D. At The Hogback, thickness of tuff is $1 \mathrm{~m}$; on north side of Tuscan Buttes, about $4 \mathrm{~m}$ posed of angular to subrounded volcanic fragments as much as $3 \mathrm{~m}$ in diameter in matrix of grayish-tan volcanic mudstone. Both composition and texture of fragments, as well as ratio of fragments to matrix, are highly varied. Scattered large irregular masses of brick-red and gray, commonly massive to locally flow-banded volcanic breccia are present within lahar deposits throughout quadrangle. Poorly sorted, polymict volcanic conglomerate, sandstone, and siltstone are interlayered with lahar deposits and increase in abundance toward west and south. Lahar deposits are generally reversely graded and range in thickness from about $0.5 \mathrm{~m}$ to $10 \mathrm{~m}$; upper and lower contacts are sharp. Total thickness of member $\mathrm{C}$ is at least 75 $\mathrm{m}$ where exposed in western part of Antelope Creek

Tti Ishi Tuff Member-Indurated but nonwelded, white to light-gray, fine-grained pumiceous air-fall tuff commonly reworked and contaminated with varied amounts of volcanic sandstone and siltstone. Readily distinguished by abundant bronze-colored mica flakes about $1 \mathrm{~mm}$ in diameter. Along Chico Monocline, Ishi Tuff Member locally separates members B and C. Preliminary potassium-argon ages obtained on biotite, hornblende, and plagioclase separated from pumice clasts are widely discordant; zircons from pumice clasts give fission-track age of about 2.6 Ma, which is currently best estimate of age of Ishi Tuff Member. Maximum thickness is $30 \mathrm{~cm}$; source unknown

Ttb Member B-Interbedded lahar deposits and volcanic conglomerate, and volcanic sandstone and siltstone; lithologically similar to rocks of member $\mathrm{C}$ except that volcanic conglomerate and volcanic sandstone are more abundant in member B. Lahar deposits and alluvial volcaniclastic rocks are interbedded in approximately equal proportions, giving more regularly layered sequence than in lahar-rich member C. Maximum thickness of conglomerate layers is about $15 \mathrm{~m}$; total thickness of member $\mathrm{B}$ is about $130 \mathrm{~m}$ along Chico Monocline

Tta Member A-Interbedded lahar deposits, volcanic conglomerate, volcanic sandstone, and siltstone, all containing scattered fragments of metamorphic rocks. Metamorphicrock fragments, which include white vein quartz, green, gray, and black chert, green- 
stone, greenish-gray slate, and serpentinite, make up less than 1 percent of rock type. Top of member A is defined by highest lahar deposit or volcanic-conglomerate layer that contains metamorphic-rock fragments. Exposures of member $\mathrm{A}$ in quadrangle are found only in canyon of Dye Creek. Thickness is unknown

Nomlaki Tuff Member-White, light-gray, locally reddish-tan to pink, dacitic pumice tuff and pumice lapilli tuff at or very near base of both Tuscan and Tehama Formations. Pumice fragments as much as 20 $\mathrm{cm}$ in diameter are generally white in lower part of member and mixture of white and light- and dark-gray in upper part. Member is generally massive, nonwelded, nonlayered ash-flow tuff well exposed at Tuscan Springs, on Antelope Creek, and at Gas Point on Cottonwood Creek, as well as at several localities south of Gas Point along west margin of valley. Maximum thickness is $25 \mathrm{~m}$ at Tuscan Springs, about $20 \mathrm{~m}$ at Antelope Creek, and $10 \mathrm{~m}$ at Gas Point. Age of Nomlaki given by Evernden and others (1964) as $3.4 \mathrm{Ma}$

Taa Basaltic andesite of Antelope Creek (Pliocene) Dark-gray to greenish-gray, locally altered to brick-red and reddish-gray, massive, highly fractured, fine-grained, sparsely vesicular basaltic andesite exposed in Antelope Creek and, to lesser extent, in Salt Creek. Red and reddish-gray scoria layers about $1 \mathrm{~m}$ thick alternate with layers of massive gray basaltic andesite of about equal thickness in western exposures of Antelope Creek and Salt Creek, suggesting that these exposures are near distal end of flow. Whole-rock

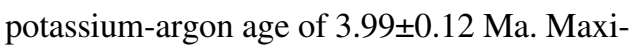
mum thickness is $15 \mathrm{~m}$

\section{SACRAMENTO VALLEY-WESTERN FOOTHILLS PROVINCE}

\section{Overlap assemblage (Late and Early Creta-} ceous)-Marine sedimentary rocks of Great Valley sequence. Unconformably overlies basement rocks of Klamath Mountains and disconformably overlies sedimentary rocks of Elder Creek terrane. Age of unit is Hauterivian to Coniacian. Divided into:

Koms Mudstone-Dark-gray mudstone and minor thin interbeds of siltstone and fine-grained sandstone; where mapped, interlayered with sandstone and conglomerate of unit Koss
Sandstone and conglomerate-Fine- to coarse-grained sandstone and local pebble to boulder conglomerate; derived from older Klamath Mountains terranes, as well as volcanic and plutonic sources, including Shasta Bally batholith

Elder Creek terrane-Divided into:

Mudstone (Early Cretaceous and Late Jurassic)-Dark-gray, hackly-fractured mudstone that contains minor tan siltstone and sandstone; nodules, lenses, and thin beds of limestone locally abundant. Relatively nonresistant unit forms valleys and swales parallel to strike

Sandstone and conglomerate (Early Cretaceous and Late Jurassic) - Fine- to coarsegrained sandstone, local conglomerate, and minor interbedded mudstone. Relatively resistant unit forms prominent topographic ridges parallel to strike

Coast Range ophiolite (Late and Middle Jurassic)—Dismembered ophiolite. Divided into:

Layered gabbro-Alternating discontinuous layers of plagioclase- and pyroxenerich gabbro. Includes minor intercalations of layered ultramafic rocks (wehrlite, clinopyroxenite, and dunite)

Layered ultramafic rocks-Wehrlite, clinopyroxenite, and dunite. As mapped, also includes minor exposures of layered gabbro Round Mountain serpentinite melangeScarce blocks as long as $500 \mathrm{~m}$ of basalt, diabase, and gabbro (gb), in sheared matrix of serpentinized dunite and minor harzburgite. Locally includes small intrusive bodies of diorite and quartz diorite

\section{COAST RANGES PROVINCE}

Landslide deposits (Holocene and Pleistocene) Glacial deposits (Pleistocene)

Pickett Peak terrane-Divided into:

South Fork Mountain Schist (Early Cretaceous, metamorphic age; protolith age unknown)Intensely crumpled and quartz-veined mica schist. Includes large bodies of fine-grained, laminated, greenish-bluish metabasalt $(\mathrm{mb})$, as well as local metachert (not mapped separately)

Valentine Spring Formation of Worrall (1981, 1982) (Early Cretaceous, metamorphic age; protolith age unknown)_Dominantly metagraywacke of textural zone $2 \mathrm{~B}$ and $3 \mathrm{~A}$ of Jayko and others (1986). Includes minor 
amounts of schistose metavolcanic rock (mv) and rare metachert (not mapped separately)

Yolla Bolly terrane-In quadrangle, divided into:

Taliaferro Metamorphic Complex of Suppe (1972) (Early Cretaceous to Middle Jurassic?)_-Schistose metagraywacke, crumpled phyllite, metagreenstone, and metachert. Metachert contains Late Jurassic radiolarians at one locality

ybc Chicago Rock melange (Early Cretaceous to Middle Jurassic)—Mostly sheared argillite, graywacke, and conglomerate that contains very abundant blocks of fine-grained greenstone (gs) and lenses of chert (ch). Also includes scarce serpentinite, rare blueschist, and amphibolite knockers (not mapped separately). Radiolarians from chert are Middle to Late Jurassic in age. Scarce Buchias are of Berriasian and Valanginian ages. Terrain commonly characterized by hummocky, grass-covered hillsides

ybh Metagraywacke of Hammerhorn Ridge (Early Cretaceous to Middle Jurassic)—Dominantly graywacke that contains lesser amounts of argillite and conglomerate, as well as abundant lenses of chert (ch) that yields fossils of Middle to Late Jurassic age. Includes scarce intrusive(?) serpentinite (sp). Generally forms resistant ridges and is commonly timber covered

ybd Broken formation of Devils Hole Ridge (Early Cretaceous to Middle Jurassic)Dominantly argillite, graywacke, and conglomerate that contains blocks and lenses of radiolarian chert (ch) and rare greenstone (not mapped separately)

\section{KLAMATH MOUNTAINS PROVINCE}

QIs Landslide deposits (Holocene and Pleistocene)_Jumbled gravitationally displaced rocks derived from adjacent bedrock

QTog Older gravel deposits (Pleistocene and (or) Pliocene)-Reddish- to yellow-brown, moderately well indurated, coarse gravel and minor amounts of coarse sand. Clasts primarily are well-rounded, light- and darkgray chert but also consist of variable but lesser amounts of metavolcanic and metasedimentary rocks that are derived from Klamath Mountains and Coast Ranges provinces

Ko Overlap assemblage (Early Cretaceous) - Depositional outliers of mudstone, sandstone, and conglomerate of Great Valley sequence that lie unconformably on basement rocks of Klamath Mountains province
$\mathrm{Ksb}$

srs

srv

$\mathrm{wh}_{1}$

$\mathrm{wh}_{2}$

$\mathrm{wh}_{3}$

$\mathrm{wh}_{4}$

whu

whpb

whpw 
age of $169 \mathrm{Ma}$ (Wright, 1981; Fahan, 1982). Plutons intrude volcanic rocks of unit $2\left(w_{2}\right)$ of western Hayfork subterrane and are preamalgamation in age

whpo

Oliphant Creek pluton (Jurassic?) - Predominantly biotite-hornblende gabbro. Intrudes volcanic rocks of unit $2\left(w_{2}\right)$ of western Hayfork subterrane and is preamalgamation in age

whpg Granite (Jurassic?)_Light-colored, medium- to coarse-grained leucocratic granite. Intrudes undivided part (whu) of western Hayfork subterrane north of Wildwood pluton and probably is preamalgamation in age

eh

Eastern Hayfork subterrane of Wright (1981, 1982) (Middle? Jurassic)-Melange and broken formation that includes argillite, quartzose sandstone, chert, limestone (Is), tuff, and serpentinized ultramafic rocks (sp). Limestone locally contains Permian (Tethyan?) foraminifers (Irwin and Galanis, 1976); radiolarians in chert yield both Triassic and Jurassic ages (Irwin and others, 1982). Unit is generally equivalent to upper unit of Hayfork terrane of Irwin (1974)

Rattlesnake Creek terrane-Divided into:

rcm

Melange (Jurassic and older)-Includes serpentinite, pillow basalt, chert, tuff, argillite, and limestone (Is). Northwest of quadrangle, unit includes chert that contains Late Triassic to Middle Jurassic radiolarians, as well as limestone that contains late Paleozoic fusulinids and Late Triassic ammonites and conodonts (Irwin, 1985b; Irwin and others, 1985)

rcds Dike and sill complex (Early Jurassic and (or) Late Triassic)_Dominantly diabase, diorite, and quartz keratophyre. Uraniumlead isotopic age of $207 \mathrm{Ma}$ measured on small segregation of plagiogranite (Wright, 1981)

rcp Plutonic rocks (Early Jurassic and (or) Late Triassic)—Gabbro, diorite, quartz diorite, and albite granite. Includes Star Mountain pluton, which is dominantly leucocratic quartz diorite. Uranium-lead isotopic age range of 193 to $204 \mathrm{Ma}$ (Wright, 1981)

rcum Ultramafic rocks (age unknown)-Mainly serpentinized harzburgite that shows tectonic fabric. Includes small bodies of dunite and local concentrations of chromite

North Fork terrane-Divided into:

nfs
Volcanic and sedimentary rocks (Jurassic to Permian)-Mafic volcanic and volcaniclastic rocks, pillow basalt, thinbedded chert, argillite, conglomerate, quartzose sandstone, and rare limestone (Is). Chert contains radiolarians of Permian, Triassic, and Jurassic ages (Irwin and others, 1982)

nfum Ultramafic rocks (Permian)-Mainly serpentinized and sheared harzburgite

$\mathrm{cm}$ Central metamorphic terrane (Devonian, metamorphic age)-Undivided wellfoliated hornblende-epidote-albite schist, quartz-mica schist, and calc schist. Includes Salmon Schist and Abrams Schist (see Irwin, 1994). Rubidium-strontium isotopic age of metamorphism is approximately $380 \mathrm{Ma}$ (Lanphere and others, 1968)

Eastern Klamath terrane-Consists of:

Redding subterrane-Divided into:

ekrb Bragdon Formation (Mississippian)Interbedded dark slaty shale and sandstone that contains local interbeds of grit and stretched-pebble conglomerate rich in chert clasts (Murphy and others, 1969)

ekrc Copley Greenstone (Devonian)-Andesitic to basaltic volcanic rocks that are, in quadrangle, metamorphosed to dark-green, fine-grained amphibolite and hornfels

ektr

Trinity subterrane (Ordovician)-Mostly serpentinized and sheared harzburgite that varies in color from light-green to black. Locally contains thin veinlets of chrysotile

\section{INTRODUCTION}

The Red Bluff $30^{\prime} \times 60^{\prime}$ quadrangle includes rocks of four major geologic provinces: the Klamath Mountains, the Coast Ranges, the Great Valley, and the Cascade Range (fig. 1, on map sheet). These rocks and their geologic histories differ greatly from one another. The Klamath Mountains are mainly an accumulation of large tectonic slices of oceanic crust, upper mantle, and volcanic island arcs that range in age from early Paleozoic to Late Jurassic. The rocks of the Coast Ranges present in the Red Bluff quadrangle consist of oceanic crustal rocks that are somewhat similar lithologically to those of the Klamath Mountains but are Early Jurassic to Cretaceous in age. The Great Valley province includes a thick deposit of moderately deformed Jurassic and Cretaceous marine strata that consist of detrital materials derived from uplifted basement rocks of the Klamath Mountains and the Sierra Nevada. In the western foothills of the Sacramento Valley, these strata rest partly on the Coast Range ophiolite and partly on the Klamath Mountains basement rocks and thus pose a complex tectonic question. In the central part of the Sacramento Valley, a mantle of Tertiary and Quaternary detrital continental deposits overlies the Great Valley se- 
quence; these deposits, which are derived from the west, grade eastward into coeval volcanic materials derived from the Cascade Range province. The stratigraphic and structural relations shown on the map provide a key to understanding how the rocks of these various provinces were formed and were subsequently assembled.

For the compilation of this geologic map, Irwin is responsible for the rocks of the Klamath Mountains province; Blake, Jayko, and Jones, the pre-Cenozoic rocks of the Coast Ranges province; Helley, the late Cenozoic deposits of the Sacramento Valley; and Harwood, the Cenozoic rocks of the Cascade Range province. Previously published geologic mapping used in this compilation is summarized in figure 2 (on map sheet).

\section{GEOLOGY}

\section{KLAMATH MOUNTAINS PROVINCE}

The northwestern part of the Red Bluff $30^{\prime} \times 60^{\prime}$ quadrangle is occupied by a metamorphic-plutonic basement complex of Jurassic and older rocks within the Klamath Mountains geologic province. Along the eastern limit of their exposure, the Klamath Mountains basement rocks are unconformably overlapped by east- to southeast-dipping, unmetamorphosed Cretaceous strata of the Great Valley sequence, which attain a stratigraphic thickness of thousands of meters. These Cretaceous strata are also preserved as erosional outliers, some of which cover areas as large as several square kilometers, that rest on basement rocks at a few places within the Klamath Mountains province. Along the southwestern edge of the province, however, the Klamath Mountains basement rocks are in fault contact with Early Cretaceous metamorphic rocks, the South Fork Mountain Schist of the Coast Ranges province.

The basement rocks of the Klamath Mountains province are divided into several allochthonous terranes (Irwin, 1972, 1977, 1994; Blake and others, 1982). These terranes have a general northwesterly trend and are separated by major faults (fig. 3, on map sheet). The terranes consist of rocks typical of oceanic crust and island arcs. The joining together or amalgamation of the terranes probably occurred sequentially from east to west, as indicated by (1) the progressive westward (oceanward) decrease in the ages of ophiolitic parts of the terranes, (2) a similar westward younging of the island-arc components, and (3) a general westward younging of metamorphic rocks that formed adjacent to the boundary faults as a result of the tectonic amalgamation process. Some terranes include plutons that are coeval with, and magmatically related to, the volcanic rocks that they intrude, forming volcano-plutonic pairs (Irwin, 1985a); these plutons, which are integral parts of a terrane, intruded their host rocks before tectonic transport and subsequent amalgamation of the host terrane to another terrane. Examples of such preamalgamation plutons in the Red Bluff quadrangle are the Wildwood, Walker Point, and other plutons of the western Hayfork subterrane of the Hayfork terrane. In contrast, the Shasta Bally batholith, which is the youngest Klamath Mountains pluton in the Red Bluff quadrangle, probably intruded during Early Cretaceous time, after all the Klamath Mountains terranes had accreted to North America. The general east-to-west succession of Klamath Mountains terranes in the Red Bluff quadrangle is the Redding and Trinity subterranes of the Eastern Klamath terrane, the Central metamorphic terrane, the North Fork terrane, the eastern and western Hayfork subterranes of the Hayfork terrane, the Rattlesnake Creek terrane, and the Smith River subterrane of the Western Klamath terrane (fig. 3, on map sheet).

The Redding subterrane is present in the Red Bluff quadrangle only as a small (about $2 \mathrm{~km}^{2}$ ) structural outlier of the Bragdon Formation and as a narrow southern extension of metamorphosed rocks belonging to the Copley Greenstone. The outlier of the Bragdon Formation, which here consists of slaty sandstone and shale, is inferred to have been thrust onto the Central metamorphic terrane along a fault that locally contains slices of serpentinite. The serpentinite presumably was derived from the nearby Trinity subterrane, which in the Red Bluff quadrangle consists entirely of serpentinized ultramafic rocks. The Central metamorphic terrane, which is separated from the Trinity subterrane by the Bully Choop Thrust Fault, includes two Devonian formations, the Abrams Schist and the Salmon Schist, which have not been mapped separately herein.

The North Fork terrane, which is separated from the Central metamorphic terrane by the Siskiyou Thrust Fault, consists of metavolcanic and metasedimentary rocks that have ophiolitic rocks at their base. In the Red Bluff quadrangle, the ophiolitic rocks of the North Fork terrane, which include ultramafic rocks, gabbro, and diabase, are highly attenuated compared to the more northerly reaches of the terrane, where they form a belt as much as several kilometers wide (Ando and others, 1983). The ophiolitic rocks are presumably Permian in age, and their overlying strata contain lenses of radiolarian chert that ranges in age from Permian to Jurassic (Blome and Irwin, 1983). North of the Red Bluff quadrangle, a few lenses of limestone in the North Fork terrane contain a Schwagerinid fusulinid fauna of Late Pennsylvanian or Early Permian age. The part of the North Fork terrane that lies south of the Trinity-Shasta County line has been mapped only in reconnaissance.

The Hayfork terrane lies west of the North Fork terrane, from which it is separated by the North Fork Thrust Fault. In the Red Bluff quadrangle, the Hayfork terrane is subdivided into two subterranes, the eastern Hayfork and western Hayfork subterranes, which are separated by the eastdipping Wilson Point Thrust Fault (Wright, 1982).

The eastern Hayfork subterrane is a melange and broken formation that occupies a zone about $9 \mathrm{~km}$ wide along the southwest side of the North Fork terrane. It mostly consists of sheared argillite, chert, and other metasedimentary 
and metavolcanic rocks but also contains scattered blocks of limestone and rare blocks of amphibolite. The chert is commonly Triassic in age but at one locality is Permian; however, no unequivocally Jurassic chert has been identified (Blome and Irwin, 1983). Some limestone of the eastern Hayfork subterrane contains late Late Permian fusulinids of Tethyan faunal affinity (Nestell and others, 1981). These fusulinids are younger than, and are faunally distinct from, the fusulinids of the adjacent North Fork terrane.

The western Hayfork subterrane in the Red Bluff quadrangle consists mainly of the Hayfork Bally Meta-andesite and the Wildwood, Walker Point, and other related plutons. The Hayfork Bally Meta-andesite is a thick, coherent sequence of volcaniclastic strata and lesser amounts of interbedded argillite and chert; in the Red Bluff quadrangle, it has been divided into four informal stratigraphic subunits (Wright, 1981). It was intruded by the preamalgamation Wildwood and other cogenetic plutons about $170 \mathrm{Ma}$ and represents a remnant of a volcanic arc of Middle Jurassic age.

The Rattlesnake Creek terrane is a melange, largely ophiolitic, that is found along the southwest side of the Western Hayfork subterrane; the terranes are separated by the Salt Creek Fault. The melange includes thin-bedded chert that contains Late Triassic to Middle Jurassic radiolarians, as well as blocks of limestone that yields both late Paleozoic fusulinids and Late Triassic ammonites and conodonts. Large units mapped separately within the melange in the Red Bluff quadrangle include a serpentinized peridotite body, which crops out in an area of about 30 square kilometers, and the preamalgamation(?) Star Mountain pluton of presumed Early Jurassic age (Wright, 1981; Irwin, 1985a).

The Western Klamath terrane has been divided into several subterranes (Blake and others, 1982); one of these is the Smith River subterrane, which forms a nearly continuous belt along the western border of the central and southern parts of the Klamath Mountains province. In the Red Bluff quadrangle, the Smith River subterrane consists of slaty shale and sandstone of the Galice(?) Formation; it crops out as discontinuous, relatively narrow fault slices that separate rocks of the Rattlesnake Creek terrane from those of the Coast Ranges. In the southernmost part of the Klamath Mountains, smaller, fault-bounded slices of the Smith River subterrane are found along the boundary between the Coast Ranges and Great Valley provinces. The significance of these slices will be discussed later.

In the Red Bluff quadrangle, the Great Valley sequence is mapped both as an overlap assemblage of Cretaceous strata and as part of the Elder Creek terrane of Jurassic and Cretaceous strata. The lower part of the overlap assemblage lies unconformably on the Klamath Mountains basement rocks north of the Cold Fork Fault Zone, while its upper part is thought to lie unconformably on the youngest strata of the Elder Creek terrane south of the fault zone. The oldest known fossil from the overlap assemblage in the Red Bluff quadrangle is Hauterivian in age, although slightly older fossils of late Valanginian age are known from the Glade Creek outlier about $20 \mathrm{~km}$ west of the quadrangle (Jones and Irwin, 1971). The overlap assemblage clearly marks the end of the Nevadan orogeny; however, it has been involved in several subsequent tectonic events, as described in the following sections.

\section{COAST RANGES PROVINCE}

The Franciscan Complex of the Coast Ranges has been divided into the Pickett Peak and Yolla Bolly terranes. Within the structurally higher Pickett Peak terrane, two distinctive units have been mapped, the South Fork Mountain Schist and the Valentine Spring Formation of Worrall (1981). These two units are believed to have been metamorphosed during the same event, although they are now separated by the Log Springs Thrust Fault.

The Yolla Bolly terrane has been subdivided into four tectonic units that are separated by thrust faults. The units are identified by differences in lithology and metamorphic grade. The structurally highest unit is the Taliaferro Metamorphic Complex of Suppe (1973), which consists of jadeite-bearing metagraywacke of textural zone 2B (Jayko and Blake, 1989), metachert, and metavolcanic rocks, the latter two of which contain distinctive blue amphibole. The structural state varies from coherent in the north to melange near Oven Lid, where the rocks have been structurally mixed with those of the underlying (informally named) Chicago Rock melange (Jayko and Blake, 1986). The contact with the overlying Valentine Spring Formation is sharply defined and has been mapped as the Sulphur Creek Thrust Fault (Worrall, 1981) on the basis of both metamorphic and structural discontinuities.

The second-highest unit, the Chicago Rock melange, also varies from relatively coherent broken formation to rather chaotic melange and contains abundant blocks of greenstone (most of which are too small to map at this scale) and lenses of chert, as well as rare knockers of blueschist and sparse intrusive serpentinite. The upper contact with the Valentine Spring Formation is, in most places, the Sulphur Creek Thrust Fault; however, in the southern part of the quadrangle, a tectonic slice of the Taliaferro Metamorphic Complex is present between these two units.

The third unit, the metagraywacke of Hammerhorn Ridge (Jayko and Blake, 1986), contains more coherent beds of graywacke and chert and less volcanic rock than any of the other units of the Yolla Bolly terrane. The upper contact has been placed at the top of the coherent sequence and is inferred to be a thrust fault, the Chicago Camp Thrust Fault, although the thrust movement probably was distributed throughout the overlying Chicago Rock melange.

The structurally lowest unit, the broken formation of Devils Hole Ridge (Jayko and Blake, 1986), is somewhat similar lithologically to the Chicago Rock melange but is usually more coherent and contains fewer blocks of green- 
stone and chert. West of the Red Bluff quadrangle, however, these two units are difficult to differentiate except where the metagraywacke of Hammerhorn Ridge intervenes. The upper contact of the Devils Hole Ridge unit is locally marked by sheared serpentinite and has been mapped at the base of the coherent Hammerhorn Ridge unit. The presence of Early Cretaceous Buchia in the Devils Hole Ridge unit below Late Jurassic radiolarians in the overlying Hammerhorn Ridge unit requires a thrust fault. However, not one of the units of the Yolla Bolly terrane is as stratally disrupted as the melange of the Central Franciscan belt (Blake and others, 1988), which lies west of the Red Bluff quadrangle.

All four units of the Yolla Bolly terrane contain lenses of radiolarian chert that were originally thought to be interbeds. Later work (Isozaki and Blake, 1994) has demonstrated, however, that these chert lenses are separated from the underlying clastic metasedimentary rocks by knife-sharp, bedding-parallel faults, which probably formed during subduction-related thrusting.

The rocks of the Pickett Peak and Yolla Bolly terranes formerly were thought to have been metamorphosed during the same Cretaceous event (Blake and others, 1967); however, more recent work (Jayko and others, 1986; Jayko and Blake, 1989) indicates that (1) a progressive eastwardly increase in textural and metamorphic grade is present in each terrane, (2) rocks of the Pickett Peak terrane contain early deformational-metamorphic structures not seen in the rocks of the Yolla Bolly terrane, and (3) a major thrust fault, the Sulphur Creek Thrust Fault of Worrall (1981), separates the two terranes. These features suggest the possibility of two separate metamorphic events. Although the exact timing of the two events is not clear, the regional geologic relation, as well as available radiometric and fossil data, suggest that both events occurred during the Cretaceous.

Along the west side of the Sacramento Valley south of the Cold Fork Fault Zone, Late Jurassic and Early Cretaceous strata of the Great Valley sequence are exposed on the steeply dipping western limb of a large syncline. Within the Red Bluff quadrangle, these strata are in fault contact with ultramafic rocks of the Coast Range ophiolite; however, 8 kilometers south of the quadrangle along the South Fork of Elder Creek, the basal Late Jurassic sedimentary rocks of the Great Valley sequence are in depositional contact with the underlying mafic breccia that marks the top of the ophiolite. The ophiolite is thought to represent oceanic crust and upper mantle upon which the Late Jurassic strata were deposited. The ophiolite and the overlying Jurassic and Early Cretaceous sedimentary rocks have been named collectively the Elder Creek terrane (Blake and others, 1982).

Although previously considered to be an older part of the overlap assemblage that rests unconformably on Klamath Mountains basement rocks to the north, the oldest sedimentary strata of the Elder Creek terrane are clearly not part of the overlap assemblage but were deposited during the Nevadan orogeny (Jones and others, 1969). This was further dis- cussed by Suppe (1973), who proposed that the "oceanic" Great Valley sequence is presumably allochthonous with respect to North America and that a major fault (subduction zone) lies hidden beneath the Cretaceous cover rocks of the Great Valley sequence. Because of renewed movement on all of the fault zones and a lack of sedimentological studies tied to the stratigraphy, the timing of stratal continuity is not clear. We have therefore arbitrarily placed the contact at the base of the Turonian-age Venado Sandstone (Durham, 1962; see also, Kirby, 1943) (not shown separately on map) because these are the oldest rocks that lie in depositional contact on Sierran basement, as shown in drill holes to the east.

\section{SACRAMENTO VALLEY AND CASCADE RANGE PROVINCES}

The eastern two-thirds of the Red Bluff quadrangle contains low-rolling topography that slopes toward the Sacramento River, the largest drainage system in northern California. This part of the quadrangle is underlain by late Cenozoic sedimentary and volcanic rocks that rest with marked unconformity on both the Late Cretaceous rocks of the Great Valley sequence and locally on the Shasta Bally batholith about $6.5 \mathrm{~km}$ northwest of Cloverdale.

The western part of the Sacramento Valley is underlain by Pliocene continental deposits of the Tehama Formation, and the eastern part is underlain by coeval volcanic rocks of the Tuscan Formation. The Nomlaki Tuff Member, which is present locally at or near the base of both the Tehama and Tuscan Formations, blanketed much of the northern Sacramento Valley about 3.4 Ma, approximately the time of major Neogene uplift and erosion of the Coast Ranges province. In the west, continental deposits of the Tehama Formation accumulated in coalescing alluvial fans along the eastern margin of the rising Coast Ranges. To the east, lahar deposits and minor lava flows, which are composed of basalt and basaltic andesite, flowed westward from several volcanic centers near Lassen Peak, $35 \mathrm{~km}$ east of the quadrangle at the southern end of the Cascade Range, forming the Tuscan Formation. Rocks of the Tehama and Tuscan Formations interfinger in a zone several kilometers wide near the present-day channel of the Sacramento River, which we have taken arbitrarily as the formation boundary.

The Tehama and Tuscan Formations were beveled and capped by the Red Bluff Formation, a thin unit of brightred gravel in a red sandy matrix. The Red Bluff Formation generally forms the highest part of the valley landscape west of the Sacramento River, where it is found as remnants of a highly dissected and eroded geomorphic surface (Helley and Jaworowski, 1985). We interpret the Red Bluff Formation to be a sedimentary cover on a pediment surface because (1) the Red Bluff apparently was deposited on a cut surface of low relief that extends regionally across various older rock types, (2) the deposits are thin and locally derived, and (3) the coarse, poorly 
sorted gravel was deposited by a very different flow regime than the one that deposited the underlying finegrained sediment of the Tehama Formation. The pediment and the gravels of the Red Bluff Formation apparently formed during a period of lateral planation by highgradient streams when impeded drainage on the Sacramento River raised local base level. Well-developed, noncalcic, brown soils (Xeralfs) of the Redding and Corning Soil Series characterize the Red Bluff Formation.

On the west side of the Sacramento Valley, all units younger than the Red Bluff are found in nested terraces usually tens of meters below the pediment surface; this depositional scheme is also partially developed on the east side of the valley, but, locally, younger alluvial deposits and volcanic rocks extend over the Red Bluff surface (Helley and others, 1981). Four such Pleistocene terrace deposits have been recognized on the west side of the Sacramento Valley; they have been correlated with the Riverbank and Modesto Formations of the San Joaquin Valley to the south (Marchand and Allwardt, 1981) on the basis of radiometric ages, soilprofile development, geomorphic expression, and superposition. In the Red Bluff quadrangle, the Riverbank and Modesto Formations are divided into informal upper and lower members. Original alluvial materials on the terraces on the west side of the valley are virtually identical lithologically, but each deposit has a characteristic elevation, degree of dissection, and amount of soil-profile development, each of which are chiefly a function of age. Terrace deposits on the east side of the Sacramento Valley are lithologically indistinguishable from each other, but the presence of volcanic debris readily distinguishes them from deposits on the west side of the valley. Correlation of east-side terrace deposits is based on the same criteria used to correlate the westside terrace deposits. Within the Pleistocene deposits, the greatest elevation difference exists between the top of the Red Bluff Formation and the highest terrace of the Riverbank Formation, the oldest Pleistocene terrace. Streams throughout the Sacramento Valley had incised their valleys tens of meters during the time between deposition of the Red Bluff and deposition of the lower member of the Riverbank, which suggests a major regional lowering of base level. The difference in terrace elevation between the lower and upper members of the Riverbank and the lower and upper members of the Modesto, however, is only a few meters.

Terrace deposits of Riverbank age are well developed and have been best preserved in the Sacramento Valley west of Anderson, near Balls Ferry, and along Cottonwood Creek and its tributaries. Riverbank-age deposits also are present along the west side of the Sacramento River south of the city of Red Bluff, as well as along Pine Creek, Reeds Creek, Red Bank Creek, Oat Creek, and Elder Creek. The terrace deposits along these streams merge eastward to form a broad terrace plain along the west bank of the Sacramento River, which extends from the city of Red Bluff south to the quadrangle boundary and beyond. In contrast to the west side, the east side of the valley displays fewer terraces and more erosional morphology.

Deposits of Modesto age are best preserved in the same areas as those of Riverbank age. The Riverbank and Modesto deposits clearly were laid down by the same watercourses that exist today; however, the volume of Holocene deposits that are accumulating at present in open, nonvegetated, sediment-filled channels along the Sacramento River and its tributaries commonly is significantly smaller than the volume of material in Modesto, Riverbank, and older deposits.

\section{TECTONIC HISTORY}

The oldest tectonic event recorded in the rocks of the Red Bluff quadrangle is the metamorphism that formed the Abrams Schist and the Salmon Schist of the Central metamorphic terrane in the Klamath Mountains province. The metamorphism occurred during Devonian time (Lanphere and others, 1968) when volcanic and sedimentary protoliths of the Central metamorphic terrane were overridden by rocks of the Trinity subterrane along the Bully Choop Thrust Fault. This subduction event may be related to the arc volcanism that resulted in the formation of the Copley Greenstone and other Devonian volcanic rocks of the overlying Redding subterrane.

The terranes west of the Central metamorphic terranethe North Fork, Hayfork, and Rattlesnake Creek terranes, as well as the Smith River subterrane of the Western Klamath terrane-were joined during a sequence of Middle and Late Jurassic events. The timing of these events is based on the ages of the youngest rocks in the terranes and on the Middle Jurassic to Early Cretaceous ages of the postamalgamation plutons that crosscut the terrane boundaries. Suturing of the westernmost rocks, the Smith River subterrane, took place in Late Jurassic time on the basis of potassium-argon isotopic ages of about $150 \mathrm{Ma}$ for the regional metamorphism of the Galice Formation (Lanphere and others, 1978). This metamorphic event probably represents part of the Nevadan orogeny.

The postamalgamation plutons are thought to result from a subduction process in which rocks of the downgoing slab are melted and then injected into the upper-plate terrane(s). Nearly all the postamalgamation plutons crop out north of the Red Bluff quadrangle. The Shasta Bally batholith, which intruded the Redding and Trinity subterranes during Early Cretaceous time, about $136 \mathrm{Ma}$ (Lanphere and others, 1968; Lanphere and Jones, 1978), is the only significant postamalgamation pluton in the quadrangle.

Paleomagnetic study of the Klamath Mountains by Mankinen and others (1989) indicated that the Permian and Triassic rocks of the Redding subterrane have rotated clockwise approximately $106^{\circ}$ relative to stable North America and that the Jurassic rocks have rotated clockwise approximately $60^{\circ}$. In addition, no paleomagnetic evidence was 
found for significant latitudinal displacement of the Klamath Mountains terranes relative to North America. Evidence from the Shasta Bally batholith indicates that major rotation virtually ceased in Early Cretaceous time when the batholith was emplaced and that, after a hiatus of about 100 m.y., during which time the Cretaceous overlap assemblage was deposited, minor rotation of the Klamath Mountains occurred as a result of extension of the Basin and Range province. The emplacement of the Shasta Bally batholith and the virtual cessation in its rotation probably mark the time of accretion of the amalgamated Klamath Mountains terranes to the North American continent.

Near Greasewood Hill in the southwestern part of the quadrangle, the Klamath Mountains, the Cretaceous overlap assemblage, the Elder Creek terrane, and the Coast Ranges join one another to form the Yolla Bolly junction (fig. 3, on map sheet; see also, Blake and Jones, 1977, 1981). The events that led to the formation of this junction are still not clearly understood despite the fact that rock distribution and age are fairly well known. Despite the uncertainties, we surmise that the formation of the Yolla Bolly junction probably involved the following sequence of events:

(1) The obduction of the Coast Range ophiolite and the lower part of the Great Valley sequence, both of which are part of the Elder Creek terrane, onto a Late Jurassic volcanic arc, the Smith River subterrane of the Western Klamath terrane, as suggested by the presence of slices of the Smith River subterrane along the western margin of the Coast Range ophiolite, both in the quadrangle and at least as far south as Elk Creek, $8 \mathrm{~km}$ south of the quadrangle in the Willows 30' $\times 60^{\prime}$ quadrangle (Jayko and Blake, 1986); the timing of this event could be as old as the Nevadan orogeny (Late Jurassic, approximately 150 $\mathrm{Ma}$ ) or as young as Early Cretaceous.

(2) The accretion (subduction) of both the Pickett Peak and Yolla Bolly terranes, probably during two different events, beneath the now-composite Klamath MountainsElder Creek terrane.

(3) The attenuation of the Elder Creek terrane by lowangle normal faulting along the Beehive Flat Fault, $3 \mathrm{~km}$ south of the quadrangle, as well as the formation of the Round Mountain serpentinite melange; these events probably commenced during subduction of lower-plate rocks and may have continued until earliest Tertiary time (Jayko and others, 1987).

(4) The westward thrusting of the Elder Creek terrane, which was accompanied by left-lateral tear faulting along the Cold Fork and Elder Creek Fault Zones (Glen, 1990); this thrusting may be a manifestation of westward thrusting of the entire Klamath Mountains over the Elder Creek terrane and the Franciscan Complex (Blake and others, 1993), and, although the timing of this event is poorly constrained in the quadrangle, farther north in southwestern Oregon the overthrusting of the Klamath Mountains onto the Franciscan Com- plex is known to have occurred between about 58 and $52 \mathrm{Ma}$ (Roure and others, 1986).

(5) The formation of the Coast Range Fault, the high-angle reverse fault that forms the present eastern and northern boundary of the Franciscan Complex (Jayko and others, 1987).

The timing of the onset of faulting along the Coast Range Fault, which was partly responsible for the uplift of the previously accreted Franciscan rocks, is not clear, but the uplift may have commenced about when the Nomlaki Tuff Member was erupted (3.4 Ma), because abundant Franciscan detritus first appears above that horizon in the Tehama Formation. Faulting probably continued throughout the time of deposition of the Red Bluff Formation and may even be active today: an earthquake swarm of more than ten events occurred near this fault from March 22 through April 4, 1982 (Jeff Howard, California Department of Water Resources, written commun., 1983).

Pliocene and younger deposits in the Sacramento Valley and eastern foothills show evidence of deformation that has occurred within the past 2.5 m.y. (Harwood, 1984; Helley and Jaworowski, 1985; Harwood and Helley, 1987). In the eastern part of the Red Bluff quadrangle, the orientation and age of late Cenozoic structures differs significantly north and south of the Red Bluff Fault. South of the Red Bluff Fault, major late Cenozoic structures strike north or north-northwest and were formed between 1.0 and 2.5 Ma. North of the Red Bluff Fault, however, late Cenozoic structures strike east-northeast and were formed less than 1.0 m.y. ago.

The northwest-trending zone of short fault segments located southeast of the city of Red Bluff marks the northern half of the Chico Monocline (Harwood and others, 1981). The monocline is a southwest-facing flexure that drapes the Tuscan Formation and underlying rocks over a steeply east dipping, high-angle reverse fault, which offsets metamorphic basement rocks about $400 \mathrm{~m}$ up-to-the-east (Harwood and Helley, 1987). The monocline was formed between 1.0 and $2.5 \mathrm{Ma}$ under the essentially east-west compressive stress that steeply thrust up the Sierran block east of the Sacramento Valley along a Mesozoic fault in the basement rocks (Harwood, 1984; Harwood and Helley, 1987). Although evidence for lateral movement during formation of the monocline is scarce, limited slickenside data suggest minor left-lateral slip (Harwood and others, 1981).

The north-trending Corning Fault, which lies west of the Chico Monocline, has no surface expression in the Sacramento Valley but is defined by seismic reflection data (Harwood, 1984; Harwood and Helley, 1987), which indicate a moderately steep, eastward dip and reverse, east-sideup movement. Upward and westward movement of the hanging wall of the fault deformed the Tehema and Red Bluff Formations into the north-trending Corning Domes, which have surface expression just south of the Red Bluff quadrangle (Helley and Jaworowski, 1985; Harwood and Helley, 
1987). The Los Molinos Syncline lies between the Corning Fault and the Chico Monocline and forms a north-northwesttrending trough that locally controls the position of the Sacramento River.

The change from north- or northwest-striking structures to east-northeast-striking structures occurs at the Red Bluff Fault, which strikes about N. $60^{\circ}$ E. diagonally across the valley subsurface and passes beneath the city of Red Bluff. Southwest of Red Bluff, the fault has no surface expression, but, northeast of the city, Pliocene volcanic rocks of the Tuscan Formation and the older gravel deposits of unit QTog are folded into a northeast-trending, southwest-plunging anticline and three small domal structures along the extended trend of the Red Bluff Fault. As far as can be determined from data available, the Red Bluff Fault appears to have normal, down-to-the-south, late Cenozoic displacement that offsets the base of the Pliocene rocks by folding and (or) faulting about $140 \mathrm{~m}$. Griscom (1973) inferred major right-lateral slip on the Red Bluff Fault from tentative correlation of offset magnetic and gravity anomalies associated with basement rocks beneath the northern part of the Sacramento Valley. No indication of major late Cenozoic lateral movement exists, but earlier strike-slip displacement cannot be ruled out.

About $25 \mathrm{~km}$ north of Red Bluff, rocks east of the Sacramento River are offset up-to-the-north along the Battle Creek Fault Zone. The amount of displacement on the fault and the height of the prominent fault scarp along Battle Creek increases significantly toward the east (Harwood and others, 1980; Harwood and Helley, 1987). West of the Sacramento River, the straight channel and valley of Cottonwood Creek is on strike with the Battle Creek Fault Zone and may, in part, coincide with the western extension of the fault. The most likely projection of the Battle Creek Fault Zone is down the South Fork of Cottonwood Creek where many linear features are found within and surrounding Quaternary terraces (Helley and others, 1981).

Although the Battle Creek Fault Zone offsets a number of older volcanic flows and its scarp is buried or draped by younger volcanic units, the movement history and slip rate of the fault are not well known. Many of the volcanic units are high-alumina basalts, which are extremely low in $\mathrm{K}_{2} \mathrm{O}$ and cannot be dated accurately by the potassium-argon method. If the volcanic fanglomerate, which is offset by the fault near the confluence of Battle Creek and the Sacramento River, correlates with the Red Bluff Formation as proposed herein, major down-to-the-south, normal faulting occurred less than 1 million years ago. The Battle Creek Fault scarp apparently channeled the ash flow that formed the 0.4-Ma Rockland ash bed of Sarna-Wojcicki and others (1982) during its emplacement. Thus, major movement on the fault may have occurred between about 0.4 and 1.0 Ma.

Between the Battle Creek and Red Bluff Faults, the major meanders of the Sacramento River are controlled by southwest-plunging folds that are referred to as the Inks Creek Fold System (Helley and others, 1981; Harwood, 1984;
Harwood and Helley, 1987). The trace of the anticline in the fold system extends northeastward from the river east of Juniper Point and merges with the Battle Creek Fault Zone near the quadrangle boundary; the synclinal trace approximately coincides with Inks Creek. West of the river, between Table Mountain and Hooker, the Pliocene Tehama Formation is arched into the Hooker Dome, which is shown clearly by the drainage pattern of Hooker Creek and Blue Tent Creek. Deformation that produced both the Inks Creek Fold System and the Hooker Dome began shortly before eruption of the Rockland ash bed, which rests unconformably across the eroded contact between the Red Bluff Formation and Tehama Formation at Round Mountain, about $2 \mathrm{~km}$ south of Juniper Point. Early phases of folding probably accompanied early movement on the Battle Creek Fault. Subsequent folding and doming produced the incised meanders of the Sacramento River and deformed the Quaternary terrace deposits on the north side of Hooker Dome, which may be as young as 250,000 yr B.P.

The kinematic relations, if any, between late Cenozoic structures in the northern part of the Sacramento Valley and those in the provinces to the west are unknown. We speculate, however, that the east-northeast-striking Battle Creek Fault Zone may extend southwestward under the South Fork of Cottonwood Creek to join the Oak Flat and Sulphur Spring Faults near the Yolla Bolly junction. Late Cenozoic movement on the Battle Creek Fault certainly has been predominantly south-side-down normal faulting, but little evidence is available on pre-late Cenozoic movement. The northeast-striking Bear Creek, Battle Creek, and Red Bluff Faults possibly reflect a broad zone of preNeogene left-lateral displacement, which accommodated movement during early Cenozoic clockwise rotations of the Klamath Mountains and the Oregon Coast Ranges (Magill and Cox, 1981).

\section{REFERENCES CITED}

Ando, C.J., Irwin, W.P., Jones, D.L., and Saleeby, J.B., 1983, The ophiolitic North Fork terrane in the Salmon River region, central Klamath Mountains, California: Geological Society of America Bulletin, v. 94, no. 2, p. 236-52.

Bailey, E.H., and Jones, D.L., 1973, Preliminary lithologic map, Colyear Springs quadrangle, California: U.S. Geological Survey Miscellaneous Field Studies Map MF-516, scale 1:48,000.

Blake, M.C., Jr., 1965, Structure and petrology of low-grade metamorphic rocks, blueschist facies, Yolla Bolly area, northern California: Stanford, California, Stanford University, Ph.D. dissertation, $91 \mathrm{p}$.

Blake, M.C., Jr., Harwood, D.S., Helley, E.J., Irwin, W.P., Jayko, A.S., and Jones, D.L., 1984, Preliminary geologic map of the Red Bluff 1:100,000 quadrangle, California: U.S. Geological Survey Open-File Report 84-105, scale 1:100,000, 22 p.

Blake, M.C., Jr., Howell, D.G., and Jones, D.L., 1982, Preliminary tectonostratigraphic terrane map of California: U.S. Geological Survey Open-File Report 82-593, scale 1:750,000.

Blake, M.C., Jr., Irwin, W.P., and Coleman, R.G., 1967, Upside- 
down metamorphic zonation, blueschist facies, along a regional thrust in California and Oregon, in Geological Survey research 1967: U.S. Geological Survey Professional Paper 575-C, p. C1-9.

Blake, M.C., Jr., Jayko, A.S., and Engebretson, D.C., 1993, The Yolla Bolly junction revisited [abs.]: Geological Society of America Abstracts with Programs, v. 25, no. 5, p. 10-11.

Blake, M.C., Jr., Jayko, A.S., McLaughlin, R.J., and Underwood, M.B., 1988, Metamorphic and tectonic evolution of the Franciscan Complex, northern California, in Ernst, W.G., ed., Metamorphism and crustal evolution of the western United States (Rubey Vol. VII): Englewood Cliffs, New Jersey, Prentice-Hall, p. 1036-59.

Blake, M.C., Jr., and Jones, D.L., 1977, Plate tectonic history of the Yolla Bolly junction, northern California: Geological Society of America Annual Meeting, Cordilleran Section 73d, Sacramento, California, 1977, Guidebook, 17 p.

1981, The Franciscan assemblage and related rocks in northern California: a reinterpretation, in Ernst, W.G., ed., The geotectonic development of California (Rubey Vol. I): Englewood Cliffs, New Jersey, Prentice-Hall, p. 307-28.

Blome, C.D., and Irwin, W.P., 1983, Tectonic significance of late Paleozoic to Jurassic radiolarians from the North Fork terrane, Klamath Mountains, California, in Stevens, C.H., ed., Pre-Jurassic rocks in western North American suspect terranes: Society of Economic Paleontologists and Mineralogists, Pacific Section, p. 77-89.

Durham, J.W., 1962, The Late Mesozoic of central California: California Division of Mines and Geology Bulletin 181, 33 p.

Evernden, J.F., Savage, D.E., Curtis, G.H., and James, G.T., 1964, Potassium-argon ages and the Cenozoic mammalian chronology of North America: American Journal of Science, v. 262, no. 2, p. 145-98.

Fahan, M.R., 1982, Geology and chronology of a part of the Hayfork terrane, Klamath Mountains, northern California: Berkeley, University of California, M.S. thesis, 127 p.

Glen, R.A., 1990, Deformation and thrusting in some Great Valley rocks near the Franciscan Complex, California, and implications for the tectonic wedging hypothesis: Tectonics, v. 9, no. 6, p. 1451-77.

Griscom, Andrew, 1973, Bouguer gravity map of California, Redding Sheet: California Division of Mines and Geology, scale $1: 250,000$.

Harwood, D.S., 1984, Evidence for late Cenozoic east-west compressive tectonism in the Sacramento Valley, California, in Crouch, J.K., and Bachman, S.B., eds., Tectonics and sedimentation along the California margin: Society of Economic Paleontologists and Mineralogists, Pacific Section, v. 38, p. 87100.

Harwood, D.S., and Helley, E.J., 1987, Late Cenozoic tectonism of the Sacramento Valley, California: U.S. Geological Survey Professional Paper 1359, 46 p.

Harwood, D.S., Helley, E.J., Barker, J.A., and Griffin, E.A., 1980, Preliminary geologic map of the Battle Creek fault zone, Shasta and Tehama Counties, California: U.S. Geological Survey Open-File Report 80-474, scale 1:24,000.

Harwood, D.S., Helley, E.J., and Doukas, M.P., 1981, Geologic map of the Chico monocline and northeastern part of the Sacramento Valley, California: U.S. Geological Survey Miscellaneous Investigations Series Map I-1238, scale 1:62,500.
Helley, E.J., and Harwood, D.S., 1985, Geologic map of the late Cenozoic deposits of the Sacramento Valley and northern Sierran foothills, California: U.S. Geological Survey Miscellaneous Field Studies Map MF-1790, scale 1:62,500.

Helley, E.J., Harwood, D.S., Barker, J.A., and Griffin, E.A., 1981, Geologic map of the Battle Creek fault zone and adjacent parts of the northern Sacramento Valley, California: U.S. Geological Survey Miscellaneous Field Studies Map MF-1298, scale $1: 62,500$.

Helley, E.J., and Jaworowski, Cheryl, 1985, The Red Bluff pediment; a datum plane for locating Quaternary structures in the Sacramento Valley, California: U.S. Geological Survey Bulletin $1628,13 \mathrm{p}$.

Huber, D.F., Nelson, S.C., Fraticelli, L.A., and Stebbins, S.A., 1983, Mineral resource potential map of the Chanchelulla roadless area, Trinity County, California: U.S. Geological Survey OpenFile Report 83-506, 14 p.

Irwin, W.P., 1972, Terranes of the western Paleozoic and Triassic belt in the southern Klamath Mountains, California, in Geological Survey research 1972: U.S. Geological Survey Professional Paper 800-C, p. C103-11.

1974, Reconnaissance geologic map of the Hayfork quadrangle, Trinity County, California: U.S. Geological Survey Miscellaneous Field Studies Map MF-576, scale 1:62,500.

1977, Review of Paleozoic rocks of the Klamath Mountains, in Stewart, J.H., Stevens, C.H., and Fritsche, A.E., eds., Paleozoic paleogeography of the western United States: Society of Economic Paleontologists and Mineralogists, Pacific Section, Pacific Coast Paleogeography Symposium 1, p. 441-54.

1985a, Age and tectonics of plutonic belts in accreted terranes of the Klamath Mountains, California and Oregon, in Howell, D.G., ed., Tectonostratigraphic terranes of the circumPacific region: Circum-Pacific Council for Energy and Mineral Resources, Earth Science Series, v. 1, p. 187-99.

1985b, Reconnaissance geologic map of the Hyampom quadrangle, Trinity County, California: U.S. Geological Survey Miscellaneous Field Studies Map MF-1809, scale 1:62,500.

1994, Geologic map of the Klamath Mountains, California and Oregon: U.S. Geological Survey Miscellaneous Investigations Series Map I-2148, scale 1:500,000.

Irwin, W.P., and Galanis, S.P., Jr., 1976, Map showing limestone and selected fossil localities in the Klamath Mountains province, California and Oregon: U.S. Geological Survey Miscellaneous Field Studies Map MF-749, scale 1:500,000.

Irwin, W.P., Jones, D.L., and Blome, C.D., 1982, Map showing sampled radiolarian localities in the western Paleozoic and Triassic belt, Klamath Mountains, California: U.S. Geological Survey Miscellaneous Field Studies Map MF-1399, scale $1: 250,000$.

Irwin, W.P., Yule, J.D., Court, B.L., Snoke, A.W., Stern, L.A., and Copeland, W.B., 1985, Reconnaissance geologic map of the Dubakella Mountain quadrangle, Trinity, Shasta, and Tehama Counties, California: U.S. Geological Survey Miscellaneous Field Studies Map MF-1808, scale 1:62,500.

Isozaki, Y., and Blake, M.C., Jr., 1994, Biostratigraphic constraints on formation and timing of accretion in a subduction complex: an example from the Franciscan Complex of northern California: Journal of Geology, v. 102, p. 283-296.

Jayko, A.S., and Blake, M.C., Jr., 1986, Significance of Klamath rocks between the Franciscan Complex and Coast Range 
ophiolite, northern California: Tectonics, v. 5 , no. 7 , p. 1055 71.

1989, Deformation of the Eastern Franciscan belt, northern California: Journal of Structural Geology, v. 11, no. 4, p. 37590.

Jayko, A.S., Blake, M.C., Jr., and Brothers, R.N., 1986, Blueschist metamorphism of the Eastern Franciscan belt, northern California, in Evans, B.W., and Brown, E.H., eds., Blueschists and eclogites: Geological Society of America Memoir 164, p. 10723.

Jayko, A.S., Blake, M.C., Jr., and Harms, Tekla, 1987, Attenuation of the Coast Range ophiolite by extensional faulting and nature of the Coast Range "thrust," California: Tectonics, v. 6, no. 4 , p. $475-88$.

Jones, D.L., Bailey, E.H., and Imlay, R.W., 1969, Structural and stratigraphic significance of the Buchia zones in the Colyear SpringsPaskenta area, California: U.S. Geological Survey Professional Paper 647-A, $21 \mathrm{p}$.

Jones, D.L., and Irwin, W.P., 1971, Structural implications of an offset Early Cretaceous shoreline in northern California: Geological Society of America Bulletin, v. 82, no. 4, p. 815-22.

Kirby, J.M., 1943, Upper Cretaceous stratigraphy of the west side of the Sacramento Valley south of Willows, Glenn County, California: Association of American Petroleum Geologists Bulletin, v. 27, no. 3, p. 279-305.

Lanphere, M.A., Blake, M.C., Jr., and Irwin, W.P., 1978, Early Cretaceous metamorphic age of the South Fork Mountain Schist in the northern Coast Ranges of California: American Journal of Science, v. 278, no. 6, p. 798-815.

Lanphere, M.A., Irwin, W.P., and Hotz, P.E., 1968, Isotopic age of the Nevadan orogeny and older plutonic and metamorphic events in the Klamath Mountains, California: Geological Society of America Bulletin, v. 79, no. 8, p. 1027-52.

Lanphere, M.A., and Jones, D.L., 1978, Cretaceous time scale from North America, in Cohee, G.V., Glaessner, M.F., and Hedberg, H.D., eds., Contributions to the geologic time scale: American Association of Petroleum Geologists, Studies in Geology, no. 6, p. 259-68.

Macdonald, G.A., 1963, Geology of the Manzanita Lake quadrangle, California: U.S. Geological Survey Geologic Quadrangle Map GQ-248, scale 1:62,500.

Macdonald, G.A., and Lydon, P.A., 1972, Geologic map of the Whitmore quadrangle, California: U.S. Geological Survey Geologic Quadrangle Map GQ-993, scale 1:62,500.

Magill, James, and Cox, Allan, 1981, Post-Oligocene tectonic rotation of the Oregon western Cascade Range and the Klamath Mountains: Geology, v. 9, no. 3, p. 127-31.

Mankinen, E.A., Irwin, W.P., and Gromme, C.S., 1989, Paleomagnetic study of the Eastern Klamath terrane, California, and implications for the tectonic history of the Klamath Mountains province: Journal of Geophysical Research, v. 94, no. B8, p. $10,444-72$.
Marchand, D.E., and Allwardt, Alan, 1981, Late Cenozoic stratigraphic units, northeastern San Joaquin Valley, California: U.S. Geological Survey Bulletin 1470, 70 p.

Maytum, J.R., 1967, Areal geology of southeast portion Chanchelulla Peak quadrangle, California: San Diego, California State University, M.S. thesis, 113 p.

Meyer, C.E., Sarna-Wojcicki, A.M., Hillhouse, J.W., Woodward, M.J., Slate, J.L., and Sorg, D.H., 1991, Fission-track age $(400,000 \mathrm{yr})$ of the Rockland tephra, based on inclusion of zircon grains lacking fossil fission tracks: Quaternary Research, v. 35, p. 367-82.

Murphy, M.A., Rodda, P.U., and Morton, D.M., 1969, Geology of the Ono quadrangle, Shasta and Tehama Counties, California: California Division of Mines and Geology Bulletin 192, 28 p.

Nestell, M.K., Irwin, W.P., and Albera, J.P., 1981, Late Permian (Early Djulfian) Tethyan foraminifera from the southern Klamath Mountains, California [abs.]: Geological Society of America Abstracts with Programs, v. 13, no. 7, p. 519.

Roure, F., Carayon, V., and Rangin, C., 1986, Évolution comparée des bassins franciscains de Californie, de l'Oregon et de Basse Californie (États-Unis et Mexique): Bulletin of the Geological Society of France, v. 8, no. 6, p. 931-44.

Sarna-Wojcicki, A.M., Meyer, C.E., Bowman, H.R., Hall, N.T., Russell, P.C., Woodward, M.J., and Slate, J.L., 1985, Correlation of the Rockland ash bed, a 400,000-year-old stratigraphic marker in northern California and western Nevada, and implications for middle Pleistocene paleogeography of central California: Quaternary Research, v. 23, p. 236-57.

Sarna-Wojcicki, A.M., Wagner, J.R., Perkins, M.E., Lajoie, K.R., and Morrison, S.D., 1982, Introduction to the tectonic and stratigraphic setting of the Humboldt basin, Humboldt County, northwestern California, in Guidebook to the Recent, Quaternary, Plio-Pliocene and Franciscan geology of western Humboldt County: National Association of Geologic Teachers, Far Western Section, Eureka, California, 1982, p. 47-59.

Suppe, John, 1973, Geology of the Leech Lake Mountain-Ball Mountain region, California: a cross section of the northeastern Franciscan belt and its tectonic implications: University of California Publications in Geological Sciences, v. 107, 82 p.

Wilson, T.A., 1961, The geology near Mineral, California: Berkeley, University of California, M.S. thesis, 94 p.

Worrall, D.M., 1981, Imbricate low-angle faulting in uppermost Franciscan rocks, south Yolla Bolly area, northern California: Geological Society of America Bulletin, v. 92, no. 10, p. 70329.

Wright, J.E., 1981, Geology and U-Pb geochronology of the western Paleozoic and Triassic subprovince, Klamath Mountains, northern California: Santa Barbara, University of California, Ph.D. dissertation, $300 \mathrm{p}$.

1982, Permo-Triassic accretionary subduction complex, southwestern Klamath Mountains, northern California: Journal of Geophysical Research, v. 87, no. B5, p. 3,805-18. 